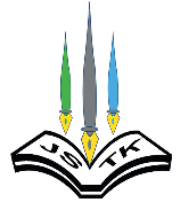

Stannum : Jurnal Sains dan Terapan Kimia

Website: https://journal.ubb.ac.id/index.php/stannum

doi: 10.33019/jstk.v2i1.1619

Review

\title{
A Review of the Development of Polymerase Chain Reaction Technique and Its Uses in Scientific Field
}

\section{Lucyenne Angeline Giri Putra, Christianus Jodi Yonathan*, Nabila Imania Niedhatrata, Mochammad Hilmy Rizka Firdaus, Jessica Renata Yoewono}

\author{
Department of Food Technology, Universitas Ciputra Surabaya \\ Region Citraland CBD Boulevard Made, Surabaya, Jawa Timur, 60219 \\ *Corresponding author: cyonathan@student.ciputra.ac.id
}

\begin{abstract}
PCR (Polymerase Chain Reaction) is a scientific term and technique in molecular biology which is able to generate copies of a specific DNA from two short oligodeoxynucleotide sequences (also called primers) by a polymerase-dependent repetitive thermal reaction. PCR technique brought a revolution in science especially in molecular biology since its first discovery back in 1984 as its simplicity and not a time-consuming trait. Over the past decades, PCR techniques have been modified to make it suitable for the application in each scientific field. PCR nowadays is involved in almost all studies that required DNA fragments manipulation including in food and medical analysis. With adequate development and proper usage, this breakthrough would be very useful for mankind in a lot of ways.
\end{abstract}

Keywords: Polymerase Chain Reaction; DNA amplification; modified technique

\section{INTRODUCTION}

PCR (Polymerase Chain Reaction) is a scientific term and technique in molecular biology which able to generate copies of a specific DNA from two short oligodeoxynucleotide sequences (also called primers) by a polymerase-dependent repetitive thermal reaction (Higuchi et al., 1993). In general, PCR is based on the quantitative relationship between the amount of the starting point target sequence and the amount of the amplified product of PCR in a cycle. This correlation creates a growing rate exponentially that raises the exact same product that is accumulated at every cycle (as $100 \%$ efficiency of the reaction occurred by the method) (Mullis et al., 1986).

PCR has been applied to many areas of study such as medical diagnosis, forensic investigation, even food analysis (Mano et al,
2014; Rodríguez-Lázaro and Hernández, 2013). This application occurs due to its versatility, specificity, and sensitivity. Accordingly in food analysis application, PCR has been successfully used for microorganism identification, for the detection of ingredients of food products and different animal and fish species. This proven usefulness made PCR a must-have tool in quality control and food safety (RodríguezLázaro and Hernández, 2013).

By the basic principle of PCR which generally amplifies DNA to be further examined, it has proven to be useful in many scientific fields (McPherson \& Moller, 2006). However, as technology and science advance there are many situational factors that require scientists to modify the PCR to suit each characteristics of the target DNA and the way to amplify them based on the current condition. Therefore, many new innovations or 
inventions of PCR techniques have been released throughout the decades. There are many scientific papers dedicated to PCR usage and applications in their own respected field. However, there are few to none articles that combine all of the methodology together to create a resume for new researchers to study and apply the principle of each PCRs. Hence, the goal of this article is to summarize the current existing methods of PCR analysis and its uses in many scientific fields so that it could be used to further improve the knowledge of PCR methodology research and also open a new possibility to further modify the existing methods for newer cases of study.

\section{PCR PRINCIPLE}

PCR could be said as a reaction that targets a specific certain molecule and is able to duplicate it by synthesizing new DNA molecules (McPherson \& Moller, 2006). The synthesized molecule is the exact complement of the DNA (Muladno, 2010). As the name of the method said, PCR used a set of proteins called polymerase to duplicate the target DNA. Polymerases are enzymes and their job is to bind individual building blocks of DNA together to form molecular sequences. In order to function well, the required supplies for these polymerases to work are a specific target DNA in the form of nucleotides and based on adenine $(A)$, cytosine $(C)$, thymine $(T)$, or guanine $(G)$. Primer or also called a small DNA fragment is needed to attach the DNA building blocks, and also basically a longer DNA molecule as a template for target DNA and to engineer new DNA strands (Innis et al., 2012; Raeymaekers, 2000).

The principle of PCR is based on thermal cycling, which exploits the thermodynamics of nucleic-acid interactions. Each cycle of PCR comprises three different temperature-steps which can be divided into 3 crucial steps according to Wahyudi (2007), Bonin et al (2003), and Henegariu et al (1997): The first step is called denaturation, in this step two double-helical DNA strands (dsDNA) are changed into two single strands DNA (ssDNA) which building in heat temperature of $950 \mathrm{oC}$. The second step is called annealing, which basically is the attachment of primers to the single-stranded DNA template from the previous process for the beginning formation of nitrogen base pairs, which occurred in 55$60^{\circ} \mathrm{C}$ temperature. The annealing process is followed by the last step called extension or elongation. In this step, nitrogen bases are extended and formed by the polymerases from the DNA templates in $72^{\circ} \mathrm{C}$ temperature.

DNA polymerase did its job in PCR reaction by sequencing a new dsDNA strand enzymatically from the DNA building blocks. The deoxyribonucleotide triphosphates (dNTPs) will bind magnesium (Mg) ions which affect the ion concentration to be effective. dNTPs are the molecules that form RNA and DNA structural units when bound together. The concentration of this effective ion is needed for the polymerization reaction which uses ssDNA as its template (Bartlett \& Stirling, 2003).

The optimization of the PCR process is necessary to obtain the optimal PCR results. In general, optimization of the PCR process can be done by varying the conditions used in the PCR process. There are several factors closely related to the optimized conditions for PCR such as the type of DNA polymerase, temperature, concentration, PCR buffer and time (Handoyo \& Rudiretna, 2000).

\section{Type of DNA polymerase}

DNA polymerases are present in many forms, in DNA polymerization reactions of PCR process, DNA installation for long strands DNA would take a different shape of DNA polymerases as the use of the DNA polymerase type depends on the length of the target DNA to be amplified. To put it simply, the ability to catalyze DNA polymerization depends on the enzyme types (Delarue et al., 1990; Ponce \& Micol, 1992).

\section{Temperature}

Temperature determines the triumph of PCR. The choice of temperature of each main step of PCR is directly related to the denaturation of the targeted DNA, annealing, and elongation stability. The efficiency of PCR based on the sufficient temperature of DNA denaturation and damage to the DNA template. Too low temperature would cause an imperfect denaturation process. The general temperature used for denaturation is $94 \mathrm{oC}$. While the general temperature of annealing used ranges from $47-60 \mathrm{oC}$, and the temperature of the elongation process is always carried out at $72^{\circ} \mathrm{C}$ as this temperature is the optimal temperature of DNA polymerase commonly used for PCR (Masny \& Plucienniczak, 2003).

\section{PCR buffer}

In general, the buffer type depends on the target DNA to be amplified. The buffer type would provide a suitable chemical environment for the DNA polymerase activity. 
For a target length of DNA between 0-5 kilobases, a low salt buffer (pH 8.75) is needed, whereas for a target length of DNA greater than five kilobases a high salt buffer ( $\mathrm{pH}$ 9.2) is used (Ponce \& Micol, 1992).

\section{Time}

Long denaturation time will potentially damage the template DNA and reduce the activity of the DNA polymerase activity at the same time. Whilst, short denaturation time will create an imperfect result of the targeted DNA. The determination of annealing process time depends on the primer length. 30 seconds is enough for the primer length of 18-22 bases template, while more than 22 bases will need a longer time of 60 seconds. The time for primer elongation depends on the length of the fragment to be amplified. In general, every one kilo of DNA bases takes 30-60 seconds.

\section{HISTORY OF PCR}

\section{The First Development of PCR}

The technique of DNA synthesis and its amplification in vitro was first developed by an American biochemist Kary Mullis in 1984. This technique was later known among scientists as Polymerase Chain Reaction (PCR). The founder Mullis received the Nobel Prize and the Japan Prize in 1993 for further development of PCR (Bartlett \& Stirling, 2003). However, the basic principle for DNA pieces replication using two primers had already been described by Gobind Khorana in 1971. This principle nonetheless was limited by polymerase purification and primer synthesis issues (Joshi \& Deshpande, 2010). In the present day, the uses of PCR involved in almost all studies required DNA fragments manipulation including in food and medical analysis as the result of its simplicity and usefulness (Ugozzoli et al., 1991). One of its most popular uses in the microbiology field is to identify a specific bacterial strain of a sample by obtaining the bacterial gene sequence and aligned it against the bacterial DNA database (Carattoli et al., 2005).

\section{Molecular Biology Revolution}

The usefulness and effectiveness of PCR technique is proven as it is possible to amplify millions of times DNA segments in a few hours. This revolutionary discovery combined with other techniques such as DNA sequencing managed to bring the science and technology field to the next revolutionary level, especially in the fields of forensic medicine, genetic disease diagnosis, and molecular evolution.
Examples of PCR techniques are used in research laboratories for DNA cloning procedures, southern blotting, DNA sequencing, recombinant DNA technology, and many more.

In forensic studies, PCR plays an invaluable role as it is used to clone a tiny amount of original DNA. When a certain DNA is found in a blood droplet or single hair strand, PCR would be the best option to clone those DNA and track down the rest of the case (Joshi \& Deshpande, 2010). In the microbiology field, PCR is usually used for microbial infections diagnosis and epidemiological studies (the study of health and disease conditions in a specific population). In the case of only a few bacteria present in a clinical specimen, the detection of the bacteria usually uses a Nested PCR technique (Apfalter et al., 2001).

PCR is also today's most sensitive test for herpes simplex virus, Varicella-Zoster virus, and Human Papillomavirus infections. Lo et al (1994) also mentioned other evolving uses of PCR for diagnostic tests such as genetic diseases, cancers, and other infectious diseases. Not to forget the quantitative PCR is used in the diagnosis of infectious diseases such as AIDS. By running this PCR test, the HIV virus can be detected during the first few weeks, faster than the standard ELISA test. Another type of RTPCR technique is also used in the viruses field. It is used in studying the RNA composed virus' genomes such as the mentioned HIV and influenza virus A. With the study using PCR techniques are applied in many fields, it is not impossible to predict a significant precision cure of an incurable disease (Maurya et al., 2005)

\section{VARIANTS OF PCR}

\section{Pretreatment Modification}

Pretreatment modification is done with the purpose of acquiring DNA, cDNA, or RNA strands specifically, so that the amplification result will also be more specific.

\section{Amplified Fragment Length Polymorphism (AFLP) - PCR}

AFLP-PCR is used to determine a different DNA fragment that is caused by insertion or deletion of nucleotide bases in a large number. AFLP-PCR is a sensitive technique that can create polymorphism between genotypes. The DNA amplification result of AFLP is more stable and more specific. The result of this method appeared as DNA tapes that translated into 
binary data according to whether or not the DNA tape presented. The result 1 given for DNA tape presence and the result 0 for the absence of DNA tape (Bintang, 2018; Vos et al., 1995).

\section{Restriction Fragment Length Polymorphism (RFLP) - PCR}

RFLP-PCR is used to analyze phylogenetic between species that have a close relative to each other (Shokohi et al., 2010; Antanassova et al., 2001). This PCR can amplify and cut DNA strands in a specific place using endonuclease restriction enzymes. The cuts then will generate smaller pieces with different sizes depending on the cutting place. These cuts then separated with agarose electrophoresis (Girish et al., 2005). The enzyme (endonuclease restriction) is usually found in prokaryotic organisms. The organisms that could generate this enzyme could protect its own genome from nucleotide methylation in the known endonuclease nucleotide sequence (Bintang, 2018). Some species have low polymorphism levels that require a suitable probe to analyze its phylogenetic between species (Bintang, 2018).

\section{Methylation-specific (MSP) - PCR}

Methylation-specific PCR (also called MSPCR) is a qualitative PCR technique used to detect methylation presence in DNA in cytosine-guanine area (CpG) that converted with bisulfate, along with characterizing the methylated parts (Herman et al., 1996). In its process, sodium bisulphate $\left(\mathrm{NaHSO}_{4}\right)$ is used to change the unmethylated cytosine base to uracil, which is then recognized by PCR primer as thymine. This process is done to generate a complementary adhesion point for adenine in primers. 2 PCR in DNA modification uses a pair of the same primer, except in some CpG areas inside the nucleotide primer sequence. One primer pair recognizes the DNA with cytosine to amplify the methylated DNA and the other primer recognizes the urasil or thymine bases to amplify the unmethylated DNA. This method depends on the modified standard PCR protocol to enable it to insert 2 sets of methylation specific primer pairs, in particular, to measure sequences that contain dinucleotide $\mathrm{CpG}$ in the analysis area (Huang et al., 2013).

\section{Reverse-Transcriptase (RT)-PCR}

RT-PCR is used to identify the cell or tissue RNA sequence, specifically for serotypes and viruses. It is performed by creating complementary DNA (cDNA) which originated from the mRNA. The formation of cDNA is done to know the message from the gene in the form of where and when the gene is expressed, and to get the gene codes (Yusuf, 2010).

\section{Primer Modification}

Primer modification technique is done to get more specific PCR result by designing the primer which complemented with the target DNA impression.

\section{Whole Genome Amplification (WGA) - PCR}

WGA-PCR is a technique used to pre-amplify genomes using random primers or their derivatives. In order to use this method, the primer must have at least 27 bases long with $65^{\circ} \mathrm{C}$ temperature (Zong et al., 2012; Bintang, 2018). This method is useful for amplifying a sample with whole genome print and is a solution for the limited DNA source information (Bouzid et al., 2010; Lasken \& Egholm, 2003).

\section{Allele-specific PCR}

As explained briefly by Imyanitov et al (2002), Allele-Specific Polymerase Chain Reaction (AS-PCR) mostly known as an Amplified Refractory Mutation System (ARMS). Basically, its method is based on using PCR to detect a single nucleotide polymorphism (SNP). This concept was first initiated by Newton et al 6 years after the PCR technique was invented. This method was specifically designed to enable DNA polymerase to amplify the 3primer end which perfectly complemented the base in a variant sequence or wild-type (Darawi et al., 2013). AS-PCR is considered as the easiest technique for SNP detection. However, it is still lacking in application because of a few inadequate constraints. In suboptimal conditions, allele-specific primer tends to strengthen both suitable and unsuitable alleles which affect heterozygote proportions (Imyanitov et al., 2002).

\section{Assembly (Polymerase Cycling Assembly / PCA) - PCR}

Long DNA molecules are made from long oligonucleotides with short overlapping parts. Primer with one overlap is used to create a product which is then utilized as an impression to build the next DNA molecules (Gibson, 2011).

\section{Symmetric PCR}

Symmetric PCR uses a probe in the form of a molecular beacon. Molecular beacon is a loop 
shaped molecule that could generate fluorescence if quencher (fluorescence absorber) detached from fluorophore (fluorescenced compound). Such an event happened when the probe successfully hibriditated with the target strand. The PCR product amount is depending on the amount of probe that hibriditate with the target strand of sample (Poddar, 2000). The cut sizes using this method could be determined around 81 bases (Bintang, 2018).

\section{Asymmetric PCR}

Asymmetric PCR can produce a vast number of ssDNAs by unequal primer concentration utilization. The production of the dsDNA involves the primer with lower concentration while the primer with higher concentration is involved in the ssDNA generation. This method involves the deletion of one primer. Throughout the primer deletion, DNA synthesis from the other strand happened arithmetically (exponentially) just like the regular PCR. Therefore, primer deletion could also decrease the annealing temperature that results in an inefficient reaction because of the limited concentration from the primer with lower melting point compared to the initial annealing temperature (Tabarzad et al., 2014; Rahman et al., 2014). Heiat (2017) stated that in order to efficiently generate a high purity ssDNA, asymmetric PCR combined with a complementary method such as enzymatic degradation of the residual strains or even gel purification could be used.

\section{Splicing by Overlap / Overhang Extension (SOE) PCR}

Overlap PCR is used to generate a recombinant gene construction by combining 2 types of DNA from different sources into one product. It is performed by elongation of primer that has complementary end without restriction enzyme usage or ligase reaction (Higuchi et al., 1988). This method includes insertion of a specific mutation process to the target DNA in nucleotide sequence. A specific primer is used to connect 2 DNA molecules with complementary sequence (Higuchi et al., 1988). The problem for using this PCR method is if the generated product is not specific and has a very little amount. This problem can be solved with dividing the reaction into two steps. The first step consists of 11-13 cycles that are processed without any primer addition and also using a lower annealing temperature so that the overlapped nucleotide sequence could be attached. The next step is 30 cycles which is done by adding the primer and high annealing temperature (Heckman \& Pease, 2007; Bryksin \& Matsumura, 2010).

\section{Linear-After-The-Exponential (LATE) - PCR}

LATE-PCR is asymmetric PCR modification which allows the generation of a large number of products after the exponential phase by using a higher melting point temperature limiting primer than the excess primer. LATEPCR more efficient and specific results compared to the conventional PCR technique allows it to be applied for single cell genetic diagnosis and high threat bioagents identification (Pierce \& Wangh, 2007).

\section{Colony PCR}

Colony PCR is intended to increase the DNA in a bacterial colony utilizing the plasmid of the bacteria. This method is done by mixing some of the colony with a restriction enzyme in the PCR mix. The denaturation process of this method uses $100^{\circ} \mathrm{C}$ temperature to take out the DNA from the bacteria cell. The plasmid is expected to be cut by restriction enzymes. The same expectation also to be in effect to the sample DNA so that the plasmid can be inserted into the sample DNA. Therefore, the bond between plasmid and sample DNA will be formed where the PCR process may occur and the DNA replication will be in process (Pavlov et al., 2006; Cao et al., 2009).

\section{Inter-Sequence-Specific (ISSR) - PCR}

Inter Sequence Specific PCR uses a single primer that has a microsatellite sequence found in one end of a 5 or 3 chain with 1-3 oligonucleotide base(s) (Zietkiewicz, et al., 1994). This sequence will ensure that primer will only be bonded to one SSR locus end. The advantage of this technique is that ISSR has a high productivity power as it is using a 16-25 pers length primer and the cheaper cost and faster result because it only needs a tiny amount of DNA (Nalini, 2004). It could detect genetic polymorphism without firstly needing to know the base sequence in all genomes (Wahyuni et al., 2004). ISSR also has a high polymorphism (Manimekalai, 2004).

\section{Inverse PCR}

Inverse PCR is one of the PCR techniques used to amplify known sequences located between two unknown sequences. Generally, the flanked sequence is a transposable element sequence. The process of Inverse PCR involved 
restriction enzymes to cut the sequence resulting in 2 sticky ends which connected and formed circular DNA in low concentration. Furthermore, the restriction enzyme will cut the known sequences of the formed circular DNA and generate a DNA chain with a known sequence in both ends, so that primer can attach and amplification process can be performed (Birbian et al., 2014).

\section{Thermal Asymmetric InterLaced (TAIL) - PCR}

TAIL-PCR is a modified PCR method which uses 2 different primer sets length and melting temperature (thermal asymmetry). TAIL-PCR is similar to Inverse PCR. This method can be used to isolate the unknown sample target sequence by flanking the nucleotide sequence to the unknown nucleotide sequence part genome. Pair of repeating primers have a difference in annealing temperature to amplify the known nucleotide sequence, primer degenerate (non repeating primer) then used to amplify the other side (unknown) nucleotide base. Primer degenerate that is used for this method is Primer Arbitrary Degenerate (AD) which is attached to the genome (Liu \& Chen, 2007). TAIL-PCR uses a nested primer with known nucleotide sequence and has a melting point $\left(\mathrm{T}_{\mathrm{m}}\right)>65^{\circ} \mathrm{C}$. Primer $\mathrm{AD}$ is a random primer that is not repeated with the length of 15-16 nucleotides with $\mathrm{T}_{\mathrm{m}}$ around $45^{\circ} \mathrm{C}$. Thus, making the amplification process efficient to generate target and non target products. This method has the advantage of being easy to be performed, efficient, and specific gene amplification results (Singer \& Burke, 2003).

\section{Random Amplified Polymorphic DNA (RAPD) - PCR}

This method is used to identify DNA polymorphism in genomes accurately and efficiently. RAPD-PCR was developed by combining the traditional PCR method using primers with random nucleotide sequences that generated a lot of DNA fragment patterns. Short oligonucleotide (usually 10 base pairs) is used in the RAPD-PCR method as a primer that will be attached with the complementary part. The primer will be attached and initiate the amplification process of a specific (or random) DNA genome area (Nanvazadeh et al., 2013; Schnell et al., 1995; Ferriol et al., 2003). The success of this technique depends on the purity and wholeness of DNA print. The impure DNA print will disturb the annealing primer and inhibit DNA polymerase activity (Bintang,
2018). The advantage of using this method is the unneeded knowledge of the organism's genome, and also its fast result. However, the disadvantage of this method is the appearance of DNA strand is inconsistent if the annealing temperature is too high (could be avoided by using more primers) and repeating DNA segments often doubled.

\section{Single-Strand Conformation Polymorphism (SSCP) PCR}

SSCP-PCR is one of the PCR techniques that could detect nucleotide differences from product DNA with the difference of 1 nucleotide. This method is suitable to detect mutation. This PCR has been used to detect mutation in humans, rats, livestocks, bacteria, and viruses. The length of the analyzed nucleotide sequence is usually around 257-500 base pairs (Tahmassebi et al., 2012; Hayashi, 1992).

\section{Nested PCR}

Nested PCR technique purpose is to reduce the contamination level of primer attachment to the inessential DNA strands. In this method, 2 primer pairs are used where both primers will go through 2 main steps. The first primer pair will attach with the target DNA and the resultant product will be used by the second primer pair as a template to attach. This process allows the end result to be more specific (Yusuf, 2010).

\section{Multiplex ligation-dependent probe amplification (MLPA) PCR}

MLPA PCR enables one primer set to amplify multiple targets. By using two oligonucleotides probes, it anneals adjacent target sites on the DNA. The sequence contained in one probe is recognized by the forward primer on the 3' to 5' DNA while the other probe contains a $5^{\prime}$ to $3^{\prime}$ strand reverse primer. The annealed respective DNA strands of both probes will ligate the probes into a complete probe. This means that unbound is not amplified. This technique is used for the analysis of microsatellites and single nucleotide polymorphisms (Hayden et al., 2008). The result of MLPA could be collected within 24 hours with fast manual work. There are more than 50 different genome locations that could be analyzed in one reaction, which could be used to diagnostic and prognostically detect genetic mutation in some tumors (Hömig-Hozel \& Savola, 2012). 


\section{Digital PCR (dPCR)}

Digital PCR is one of the quantitative PCR techniques where the PCR result can be automatically detected. This technique works by dividing the initial sample into a partition (microwell), followed by the usual PCR procedure. The result will be detected through fluorescence. The difference of dPCR and qPCR is the result of dPCR amount could be surely determined by looking at the fluorescent microwell and digitally detected. This reason made dPCR said to be an absolute quantitative PCR (Quan et al., 2018). The potential applications of $\mathrm{dPCR}$ are ranging in a wide area such as quantification of low-level pathogens, rare genetic sequences, copy number variations, and relative gene expression in single cells (Joshi \& Deshpande, 2010).

\section{Modified Amplification \\ Quantitative/Real-Time (q) PCR}

Time

qPCR is an analysis method developed from traditional PCR reaction. The qPCR technique is used to determine a target DNA concentration using the primer that usually reaches the length of $>300$ base pairs. qPCR is a fast and sensitive technique suitable for direct microbial detection and identification (LyChatain et al, 2011). qPCR is performed by adding colorant in the form of fluorescence or probe fluorescence DNA oligonucleotide. The colorant from the fluorescence or the mentioned probe will later bind with the target DNA and glow. The more fluorescent result meant a high DNA target concentration (Logan et al., 2009). The sample that could be amplified using this method include DNA, cDNA, and RNA.

qPCR used a probe in its process. There are 2 kinds of fluorescent probes that are widely used, DNA binding dyes (intercalated with DNA) and probe-based chemistries. The probe is bound to the $5^{\prime} \mathrm{P}$ and $3^{\prime} \mathrm{OH}$ end in DNA nucleotide sequences. The $5^{\prime} \mathrm{P}$ end probe has the reporter dye system that could generate fluorescence and the $3^{\prime} \mathrm{OH}$ end probe has a quencher that could muffle fluorescence of the reporter dye. The reporter part then hydrolyzed by DNA polymerase during the DNA synthesis process. The hydrolyzed reporter dye then releases fluorescence emission that could be detected by the detector. In general, the qPCR method is similar to the classic PCR principle. The difference is only on the amplified DNA that is counted after accumulated in a real-time reaction after all amplification cycle ends (Bintang, 2018).

\section{Modified Amplification Temperature Touchdown gene amplification PCR}

In Touchdown PCR, the temperature used at the beginning of the annealing process is $3-5^{\circ} \mathrm{C}$ higher than the average PCR technique. Within each cycle, the temperature is set to be lower so that in the later cycles become $3-5^{\circ} \mathrm{C}$ lower than normal. This technique is performed because of the greater primer binding specificity in earlier cycles occurred in higher annealing temperature while lower later cycles temperature leads to more efficient amplification of the reduced primer concentration (Patel et al., 2015).

\section{Hot-Start/Cold-Finish PCR}

Hot Start PCR is made to reduce the nonspecific DNA amplification in a temperature lower than $94^{\circ} \mathrm{C}$, wherein this temperature PCR is entering the annealing process (Hoy, 2013). Hot Start PCR is generally used for a slight amount of sample in order to get the more specific result and the amount of the wanted amplicon not reduced. This technique is applied by using a high melting point wax to confine sample and DNA polymerase enzyme so that both of them will only mix in the annealing step. This technique is not popularly used nowadays as according to Coleman and Tsongalis (2016), there is a developed polymerase which is only active in a certain temperature that makes it possible to be mixed with other components.

\section{Co-Amplification at Lower Denaturation Temperature (COLD) - PCR}

This PCR technique uses a critical denaturation temperature (Tc) which is significantly lower compared to the other PCR techniques in general. It is applied to DNA with less than 200 base pairs long. In general, Zuo and Jabbar (2016) said that this COLD-PCR is used to detect mutation in DNA. COLD-PCR can be divided into Full COLD-PCR which enables the formation of heteroduplex (the bond between mutant and wild type gene) and Fast COLD-PCR which almost never form a heteroduplex (Liang et al., 2018).

In this PCR, diverse alel amplified from the mixed type and DNA that contains controlled mutation. The diversity is used to detect cancer in the medical world. This method is also used to detect low level DNA mutation using reamplification with low denaturation 
temperature. COLD-PCR is a new PCR type which is able to amplify minor alel from the mixed type (Milbury \& Makrigiorgos, 2010; How Kit et al., 2013). Amplification of this PCR generates a high percentage of diverse alel. Mutation increase through COLD-PCR is more efficient for shorter nucleotide sequences with $<20$ base pairs (Bintang, 2018).

\section{APPLICATION IN FOOD ANALYSIS}

\section{Food Analysis and Authentication}

PCR method is widely used in microbial analysis in food. For food industries and regulatory agencies, microbiological safety is an important concern in food production. As in the marketing effect, this analysis purposely was done to avoid any further bad consequences to human health that will lead to economic and consumer trust losses (Klancnik et al., 2012). is one of the most needed matters in food products regarding the increase in consumer awareness. Food industry must always provide the exact labels that can be verified by anyone in further analysis as incorrect labeling could be considered as commercial fraud. Misleading labeling would affect consumers' health, especially to nondeclared potential allergens.

One of the incorrect and commercial frauds is the mix of beef and pork meat. Calvo et al (2002) developed and evaluated a semiquantitative PCR technique that able pork detection in ground beef and paste by targeting a repetitive DNA element (SINE) such as phosphodiesterase/ ryanodine/myostatin (Laube et al., 2003). The result showed that there is a specific $0.005 \%(\mathrm{w} / \mathrm{w})$ pork in heated and beef. This technique has successfully proven commercial fraud by the addition of pork meat. Pork addition valuation in meat mixtures also analyzed quantitatively using a real-time PCR with TaqMan probes (Rodriguez et al., 2005).

Another example is the goat milk in sheep milk detection using qPCR targeting the $12 \mathrm{~S}$ rRNA gene with the detection limit up to $0.5 \%$ (Lopez-Calleja, 2007). The multiplex PCR technique is also used and developed by Bottero et al (2003) to detect cow, sheep, and goat's milk in cheese concluded by $12 \mathrm{~S}$ and $16 \mathrm{~S}$ rRNA mitochondrial genes with detection limits up to $0.5 \%$.

\section{Food Labelling}

According to Poms et al (2004), storage protein or gluten contained in cereals (wheat, rye, and barley) is able to damage the small intestinal mucosa of celiac diseased patients. Therefore, an essential gluten-free diet is considered for these people, thus to avoid haphazard consumption of a product that contains gluten, a qualified and validated labeling is important. According to the draft revised standard for gluten-free foods of Codex Alimentarius Commission (2006), "gluten-free foods are foodstuffs consisting of or made only from ingredients which do not contain any prolamins from wheat or all Triticum species such as spelt, kamut or durum wheat, rye, barley, oats not exceeding $0.002 \%(\mathrm{w} / \mathrm{w})$, or foods consisting of ingredients from wheat, rye, barley oats, spelt with a gluten level not exceeding $0.02 \%(\mathrm{w} / \mathrm{w})$ on a dry matter basis."

Poms et al (2004) said that gluten detection in food products is based on protein analysis. However, real-time PCR technique is also used as an alternative to immunological assays. Good correlation between protein assays in wheat ( $\omega$-gliadin), rye ( $\omega$-secalin), oats (avenin), and barley (hordey) is found by using melting curve analysis for identification of product which established specific discrimination limit detection of 0.01 to $0.1 \%$ (Sanberg et al., 2003).

Allergen containing food products' presence in the market could be effectively avoided by foodstuffs labeling. However, processed food products contain vast ingredient varieties which are sometimes difficult to avoid by an allergic individual, even though it is still possible to selectively pick a suitable food product, but total avoidance is nonetheless nearly possible. To improve consumer protection and compliance ensurement, dependable detection and quantification methods for food allergens are very important. One of the potential food allergens contained in food ingredients is hazelnut. Hazelnut is often used as an ingredient in pastries, confectionary products, ice cream, or also furthermore processed into oils. These types of potential allergens can be using a real-time PCR technique with TaqMan probes just like the other mentioned analysis. The attempted experiment of hazelnut detection in food had a practical detection limit of $0.01 \%(\mathrm{w} / \mathrm{w})$ hazelnut in pastry mode samples (Piknova, 2008).

\section{Genetically Modified Organism (GMO)}

A revolution had come in the agricultural field during the past decade with the introduction of Genetically Modified Organisms (GMO) which marked the rapid development of 
biotechnology. Not like fortification which only adds desired compounds into a food product (Dary \& Hurrell, 2006), GMO takes it to the molecular level of modifying the base DNA structure and combining it with other DNA to create a modified organism that is expected to be beneficial for humans (Ahmed, 2002). This revolutionary discovery had reaped many pros and cons among scientists since it entered the food chain. Public debate talking and concerning the food safety and labeling information rose especially in European countries. For this reason of contradictions, the EU paid special attention to the disagreed consumer by making compulsory labeling for food products with more than $0.9 \%$ GMO (EU EC, 2003). Multiplex PCR technique has proven to be the most effective method for GMO presence check in the food product as it saves considerable time and effort by decreasing the number of reactions required to assess by simultaneously amplifying multiple sequences at once. As an example, for this reason, several approaches based on multiplex PCR had been developed such as Genetically Modified (GM) maize lines, GM canola lines, and roundup ready (RR) soybean (Germini et al., 2004). It is also described by Hernandez et al (2005) that multiplex PCR technique is able to detect several GM maize lines (Bt11, MON810, T25 e GA21), which proved to be $100 \%$ specific to the events Bt11, MON810 and GA21.

\section{Food Safety and Quality Control}

Bacterial detection and control are two key aspects in food microbiology (Stewart, 1997). Microbiological quality control programmes are increasingly applied throughout food chain production in order to minimize the risk of infection for the consumer. Thus, the availability of reliable, rapid and accepted test systems to detect the presence or absence, or even the degree of contamination of pathogens, becomes increasingly important for the agricultural and food industry. Such systems would also find a place within the framework of legislative control measures. During the last 15 years, PCR has significantly contributed to this field (Valasek and Repa, 2005; RodríguezLázaro, 2013).

Traditional methods of detection, although reliable and efficient, require several days to weeks before results are produced. Furthermore, phenotypic properties by which the bacteria are identified may not be always expressed; and when expressed, they may be difficult to interpret and classify. Another disadvantage of traditional methods is that cells which are viable but otherwise nonculturable cannot be detected, e.g. some stressed Campylobacter spp. (Rodríguez-Lázaro and Hernández, 2013)

Speed, excellent detection limit, selectivity, specificity, sensitivity and potential for automation are among the most important advantages of qPCR. These advantages compared to traditional detection methods might well encourage end-users to adopt amplification techniques in routine testing for food-borne pathogens (Rodríguez-Lázaro \& Hernández, 2013).

One example of PCR usage in quality control is the identification of Listeria spp and $L$ monocytogenes in ready to eat salad in Italia. Ready to eat salad is one of the foods that needs to be examined carefully because it is consumed in raw condition that makes it vulnerable to microbial contamination. Moreover, $L$ monocytogenes can also grow in a vast range of temperatures and $\mathrm{pH}$. Therefore, a quick testing method needs to be done. The analysis of this microorganism is using Multiplex PCR technique after the ready to eat salad is firstly isolated and suspected to be contaminated. Multiplex PCR is used to separate species between Listeria genus. The study had shown a $6 \%$ contamination of the mentioned microorganisms with species variations ( $Q$ Nabi et al, 2011). This type of study will not be able to conduct easily without a PCR method. By doing this study and acknowledging the microorganisms characteristics, researchers are able to identify and also prevent the further growth of the respected microorganisms that could possibly threaten consumer experience of ready to eat salad.

Another example in the food safety field is the determination of Fusarium head blight (FHB) produced by Fusarium spp. of complex widespread disease of the small grains (maize, wheat, or barley). Besides the considerable loss of yield, it has the ability to produce mycotoxins which are harmful to human and animal consumers. For this reason it is of great importance to identify Fusarium infections before the toxins are synthesized and in the same time to determine its toxigenic potential (Boldura and Popescu, 2016).

\section{ADVANTAGES AND LIMITATIONS}

It has been shown that PCR has so many advantages as a simple to understand and use technique which produces results rapidly 
(Garibyan \& Avashia, 2013). It is a highly sensitive technique with the potential to produce millions to billions of copies of a specific product for sequencing, cloning, and analysis. In biochemistry principle, PCR amplifies DNA of living organisms in Vitro so that it is suitable for every organism. PCR is also able to measure analyte with minimum time, selectively, specifically, and sensitively with almost full automatic process (RodriguezLazaro \& Hernández, 2013). Moreover, PCR is performed in a closed reaction vessel that requires no post-PCR manipulations, thereby minimizing the chances for cross contamination in the laboratory (Valasek \& Repa, 2005).

Although PCR is a valuable technique, it does have some limitations. Because PCR is a highly sensitive technique, any form of contamination of the sample by even trace amounts of DNA can produce misleading results (Smith \& Osborn, 2009). In addition, in order to design primers for PCR, some prior sequence data is needed. Therefore, PCR can only be used to identify the presence or absence of a known pathogen or gene. Another limitation is that the primers used for PCR can anneal non-specifically to sequences that are similar, but not completely identical to target DNA. In addition, incorrect nucleotides can be incorporated into the PCR sequence by the DNA polymerase, even though at a very low rate (Garibyan \& Avashia, 2013). It is also proven that the lack of special care of the equipment can lead to a contamination of the sample, take the example of food safety field the lack of special treatment of the equipment can lead to a misleading result of a wrong amplified target (De Medici et al, 2015). Therefore, a special precaution is absolutely necessary to operate this sensitive equipment.

\section{CONCLUSIONS}

PCR technique has been rapidly developing in the past decades with many modified techniques and methods now present in this modern era. The usefulness and effectiveness of PCR enable many fields such as medical, forensic, agriculture, food science, and molecular biology to develop further by taking advantage of its function in DNA amplification. PCR is one of the revolutionary techniques in science which if developed and used well will be very beneficial for humanity in many aspects.

\section{REFERENCES}

Atanassova, V., Meindl, A., \& Ring, C. (2001). Prevalence of Staphylococcus aureus and Staphylococcal enterotoxins in raw pork and uncooked smoked ham - A comparison of classical culturing detection and RFLP-PCR. International Journal of Food Microbiology, 68(1-2),105-113.

https://doi.org/10.1016/S01681605(01)00479-2

Atkins, T. (1995). Identification of cultivars and validation of genetic relationships in Mangifera indica L . using RAPD markers. 269-274.

Balacs, T. (1997). Research reports. International Journal of Aromatherapy, 8(2), 43-45.

https://doi.org/10.1525/jlca.1992.4.2.99

Bintang, M. (2018). Biokimia Teknik Penelitian. In Biokimia Teknik Penelitian (Second Edition) (2nd ed.). Erlangga.

Boldura, O. M., \& Popescu, S. (2016). PCR: A Powerful Method in Food Safety Field. Biochemistry, Genetics and Molecular Biology" Polymerase Chain Reaction for Biomedical Applications". Intech Publishers, USA, 135-158.

Bonin, S., Petrera, F., Niccolini, B., \& Stanta, G. (2003). PCR analysis in archival postmortem tissues. Journal of Clinical Pathology - Molecular Pathology, 56(3), 184186. http://dx.doi.org/10.5772/65738.

Bottero, M. T., Civera, T., Nucera, D., Rosati, S., Sacchi, P., \& Turi, R. M. (2003). A multiplex polymerase chain reaction for the identification of cows', goats' and sheep's milk in dairy products. International Dairy Journal, 13(4), 277-282. https://doi.org/10.1016/S09586946(02)00170-X

Bouzid, M., Heavens, D., Elwin, K., Chalmers, R. M., Hadfield, S. J., Hunter, P. R., \& Tyler, K. M. (2010). Whole genome amplification (WGA) for archiving and genotyping of clinical isolates of Cryptosporidium species. Parasitology, 137(1), 27-36. https://doi.org/10.1017/S0031182009991 132

Bryksin, A. V., \& Matsumura, I. (2010). Overlap extension PCR cloning: A simple and reliable way to create recombinant plasmids. BioTechniques, 48(6), 463-465. https://doi.org/10.2144/000113418

Calvo, J. H., Osta, R., \& Zaragoza, P. (2002). Quantitative PCR detection of pork in raw and heated ground beef and pâté. Journal of Agricultural and Food Chemistry, 50(19), 5265-5267. https://doi.org/10.1021/jf0201576 
Cao, M., Fu, Y., Guo, Y., \& Pan, J. (2009). Chlamydomonas (Chlorophyceae) colony PCR. Protoplasma, 235(1-4), 107-110. https://doi.org/10.1007/s00709-0090036-9

Carattoli, A., Bertini, A., Villa, L., Falbo, V., Hopkins, K. L., \& Threlfall, E. J. (2005). Identification of plasmids by PCR-based replicon typing. Journal of Microbiological Methods, 63(3), 219-228. https://doi.org/10.1016/j.mimet.2005.03.0 18

Commission, C. A. (2006). Codex Alimentarius Commission. (2006). Draft revised standard for gluten-free foods. Report of the 28th Session of the Codex Committee on Nutrition and Foods for Special Dietary Uses (ALINORM 07/30/26). Joint FAO/WHO Food Standards Programme. Rome.

Darawi, M. N., Ai-Vyrn, C., Ramasamy, K., Hua, P. P. J., Pin, T. M., Kamaruzzaman, S. B., \& Majeed, A. B. A. (2013). Allele-specific polymerase chain reaction for the detection of Alzheimer's disease-related single nucleotide polymorphisms. BMC Medical Genetics, 14(1). https://doi.org/10.1186/1471-2350-14-27

Dary, O., Hurrell, R. (2006). Global Progress Food Fortification. Unscn.Org, 341. https://doi.org/10.1242/jeb.02490

De Medici, D., Kuchta, T., Knutsson, R., Angelov, A., Auricchio, B., Barbanera, M., ... \& Tomic, D. H. (2015). Rapid methods for quality assurance of foods: the next decade with polymerase chain reaction (PCR)-based food monitoring. Food analytical methods, 8(2), 255-271.doi:10.1007/s12161-0149915-6.

European Commission. (2003). Regulation (Ec) No 1830/2003 ff The European Parliament and of The Council of 22 September 2003 concerning the traceability and labelling of genetically modified organisms and the traceability of food and feed products produced from genetically modified 0 . Official Journal of the European Union, 31(1830), 24-28.

Ferriol, M., Picó, M. B., \& Nuez, F. (2003). Genetic diversity of some accessions of Cucurbita maxima from Spain using RAPD and SBAP markers. Genetic Resources and Crop Evolution, 50(3), 227-238. https://doi.org/10.1023/A:102350292576 6

Garcl, T., Gonza, I., Rodrı, M. A., Martı, R., \& Herna, P. E. (2005). MEAT TaqMan real-time PCR for the detection and quantitation of pork in meat mixtures. 70, 113-120. https://doi.org/10.1016/j.meatsci.2004.12. 005

Garibyan, L., \& Avashia, N. (2013). Research techniques made simple: polymerase chain reaction (PCR). The Journal of investigative dermatology, 133(3), e6. doi: 10.1038/jid.2013.1

Georgiou, M., Hatzaki, A., \& Koutselinis, A. (2000). Identification of an alleged offender of murder by VNTR analysis: Case report. American Journal of Forensic Medicine and Pathology, 21(2), 162-165. https://doi.org/10.1097/00000433200006000-00014

Germini, A., Zanetti, A., Salati, C., Rossi, S., Forré, C., Schmid, S., \& Marchelli, R. (2004). Development of a seven-target multiplex PCR for the simultaneous detection of transgenic soybean and maize in feeds and foods. Journal of Agricultural and Food Chemistry, 52(11), 3275-3280. https://doi.org/10.1021/jf035052x

Gibson, D. G. (2011). Enzymatic assembly of overlapping DNA fragments. Methods in Enzymology, 498, 349-361. https://doi.org/10.1016/B978-0-12385120-8.00015-2

Girish, P. S., Anjaneyulu, A. S. R., Viswas, K. N., Shivakumar, B. M., Anand, M., Patel, M., \& Sharma, B. (2005). Meat species identification by polymerase chain reactionrestriction fragment length polymorphism (PCR-RFLP) of mitochondrial 12S rRNA gene. Meat Science, 70(1), 107-112. https://doi.org/10.1016/j.meatsci.2004.12. 004

Handoyo, D., \& Rudiretna, A. (2001). Prinsip umum dan pelaksanaan Polymerase Chain Reaction (PCR). Unitas, 9(1), 17-29.

Hayashi, K. (1992). PCR-SSCP: A method for detection of mutations. Genetic Analysis: Biomolecular Engineering, 9(3), 73-79. https://doi.org/10.1016/10503862(92)90001-L

Hayden, M. J., Nguyen, T. M., Waterman, A., \& Chalmers, K. J. (2008). Multiplex-Ready PCR: A new method for multiplexed SSR and SNP genotyping. BMC Genomics, 9, 1-12. https://doi.org/10.1186/1471-2164-9-80

Heckman, K. L., \& Pease, L. R. (2007). Gene splicing and mutagenesis by PCR-driven overlap extension. Nature Protocols, 2(4), 924-932. https://doi.org/10.1038/nprot.2007.132

Heiat, M., Ranjbar, R., Latifi, A. M., Rasaee, M. J., \& Farnoosh, G. (2017). Essential strategies 
to optimize asymmetric PCR conditions as a reliable method to generate large amount of ssDNA aptamers. Biotechnology and Applied Biochemistry, 64(4), 541-548. https://doi.org/10.1002/bab.1507

Henegariu, O., Heerema, N. A., Dloughy, S. R., Vance, G.H., \& Vogt, P. H. (1997). Multiplex PCR: critical parameters and step-by-step protocol (pp. 23,(3),504-511). pp. 23,(3),504-511. Biotechniques.

Herman, J. G., Graff, J. R., Myöhänen, S., Nelkin, B. D., \& Baylin, S. B. (1996). Methylationspecific PCR: A novel PCR assay for methylation status of $\mathrm{CpG}$ islands. Proceedings of the National Academy of Sciences of the United States of America, 93(18), 9821-9826. https://doi.org/10.1073/pnas.93.18.9821

Hernández, M., Rodríguez-Lázaro, D., Zhang, D., Esteve, T., Pla, M., \& Prat, S. (2005). Interlaboratory transfer of a PCR multiplex method for simultaneous detection of four genetically modified maize lines: Bt11, MON810, T25, and GA21. Journal of Agricultural and Food Chemistry, 53(9), 3333-3337. https://doi.org/10.1021/jf049192y

Higuchi, R., Krummel, B., \& Saiki, R. (1988). A general method of in vitro preparation and specific mutagenesis of DNA fragments: study of protein and DNA interactions. (pp. 16 (15), 7351-7367). pp. 16 (15), 7351-7367.

Higuchi, R., Fockler, C., Dollinger, G., \& Watson, R. (1993). Kinetic PCR analysis: Real-time monitoring of DNA amplification reactions. Bio/Technology, 11(9), 1026-1030. https://doi.org/10.1038/nbt0993-1026

Hömig-Hölzel, C., \& Savola, S. (2012). Multiplex Ligation-dependent Probe Amplification (MLPA) in tumor diagnostics and prognostics. Diagnostic Molecular Pathology, 21(4),

189-206. https://doi.org/10.1097/PDM.0b013e3182 595516

How Kit, A., Mazaleyrat, N., Daunay, A., Nielsen, H. M., Terris, B., \& Tost, J. (2013). Sensitive detection of KRAS mutations using enhanced-ice-COLD-PCR mutation enrichment and direct sequence identification. Human Mutation, 34(11), 1568-1580. https://doi.org/10.1002/humu.22427

Hoy, M. A. (2013). Insect Molecular Genetics : An Introduction to Principles and Application (3rd ed.). Academic Press.

Imyanitov, E. N., Buslov, K. G., Suspitsin, E. N., Kuligina, E. S., Belogubova, E. V., Grigoriev, M. Y., ... Hanson, K. P. (2002). Improved reliability of allele-specific PCR. BioTechniques, 33(3), 484-490. https://doi.org/10.2144/02333bm04_1184 $1 \mathrm{a}$

Irvine, R. F., \& Press, R. (1991). DNA Music : An Audio Aid Methods in Inositide Research PCR Protocols-A Guide to Methods and Applications. 19(1), 1991.

Jagtar Singh , Niti Birbian, S. S. and A. G. (2014). A critical review on PCR, its types and applications. International Journal of Advanced Research in Biological Sciences, 1(7), 65-80. Retrieved from http://www.ijarbs.com/pdfcopy/oct2014/ij arbs11.pdf

Joshi, M., \& Deshpande, J. D. (2011). Polymerase Chain Reaction: Methods, Principles and Application. International Journal of Biomedical Research, 2(1). https://doi.org/10.7439/ijbr.v2i1.83

Klancnik, A., Kovac, M., Toplak, N., Piskernik, S., \& Jersek, B. (2012). PCR in Food Analysis. Polymerase Chain Reaction, (May). https://doi.org/10.5772/38551

Kuchta, L. P. D. P. T. (2008). A novel real-time polymerase chain reaction ( $P C R$ ) method for the detection of hazelnuts in food. 11551158. https://doi.org/10.1007/s00217007-0644-6

Lasken, R. S., \& Egholm, M. (2003). Whole genome amplification: Abundant supplies of DNA from precious samples or clinical specimens. Trends in Biotechnology, 21(12), 531-535.

https://doi.org/10.1016/j.tibtech.2003.09.0 10

Laube, I., Spiegelberg, A., Butschke, A., Zagon, J., Schauzu, M., Kroh, L., \& Broll, H. (2003). Methods for the detection of beef and pork in foods using real-time polymerase chain reaction. International Journal of Food Science and Technology, 38(2), 111-118. https://doi.org/10.1046/j.13652621.2003.00651.x

Liang, H., Chen, G.-J., Yu, Y., \& Xiong, L.-K. (2018). Co-amplification at lower denaturation temperature-PCR: methodology and applications. Yi Chuan = Hereditas, 40(3), 227-236. https://doi.org/10.16288/j.yczz.17-369

Liu, Y. G., \& Chen, Y. (2007). High-efficiency thermal asymmetric interlaced PCR for amplification of unknown flanking sequences. BioTechniques, 43(5), 649-656. https://doi.org/10.2144/000112601

Lo, A. C., \& Feldman, S. R. (1994). Polymerase chain reaction: Basic concepts and clinical applications in dermatology. Journal of the 
American Academy of Dermatology, 30(2), 250-260. https://doi.org/10.1016/S01909622(94)70025-7

López-Calleja, I., González, I., Fajardo, V., Martín, I., Hernández, P. E., García, T., \& Martín, R. (2007). Quantitative detection of goats' milk in sheep's milk by real-time PCR. Food Control, 18(11), 1466-1473. https://doi.org/10.1016/j.foodcont.2006.11 .006

Ly-Chatain, M. H., Durand, L., Rigobello, V., Vera, A., \& Demarigny, Y. (2011). Direct quantitative detection and identification of Lactococcal bacteriophages from milk and whey by real-time PCR: application for the detection of Lactococcal bacteriophages in Goat's raw milk whey in France. International journal of microbiology, 2011. doi:10.1155/2011/594369

Mano, J., Hatano, S., Futo, S., Yoshii, J., Nakae, H., Naito, S., ... \& Kitta, K. (2014). Development of a reference material of a single DNA molecule for the quality control of PCR testing. Analytical chemistry, 86(17), 86218627.

Manimekalai, R., Nagarajan, P., \& Bharathi, M. (2004). DNA polymorphism among coconut (Cocos nucifera L.) cultivars. Journal of Plantation Crops, 32, 117-122.

Marmiroli, N., \& Maestri, E. (2007). Polymerase chain reaction (PCR). Food Toxicants Analysis, $\quad$ 5(6), 147-187. https://doi.org/10.1016/B978-0444528438/50007-9

Masny, A. (2003). Ligation mediated PCR performed at low denaturation temperatures--PCR melting profiles. Nucleic Acids Research, 31(18), 114e - 114. https://doi.org/10.1093/nar/gng116

Maurya, R., Singh, R. K., Kumar, B., Salotra, P., Rai, M., \& Sundar, S. (2005). Evaluation of PCR for diagnosis of Indian kala-azar and assessment of cure. Journal of Clinical Microbiology, 43(7), 3038-3041. https://doi.org/10.1128/JCM.43.7.30383041.2005

Milbury, C. A., Li, J., \& Makrigiorgos, G. M. (2011). Ice-COLD-PCR enables rapid amplification and robust enrichment for low-abundance unknown DNA mutations. Nucleic Acids Research, 39(1), 1-10. https://doi.org/10.1093/nar/gkq899

Miller, S. A., Gallie, D. R., Sleat, D. E., Watts, J. W., Turner, P. C., \& Wilson, T. M. a. (1988). Volume 16 Number 31988 Nucleic Acids Research. Nucleic Acids Research, 16(3), 883-893.
McPherson, M., \& Møller, S. (2006). Pcr. Taylor \& Francis.

Moras, D., \& Argos, P. (1990). An attempt to unify the structure of polymerases. Protein Engineering, Design and Selection, 3(6), 461467.

https://doi.org/10.1093/protein/3.6.461

Mullis, K., Faloona, F., Scharf, S., Saiki, R., Horn, G., \& Erlich, H. (1992). Specific enzymatic amplification of DNA in vitro: the polymerase chain reaction. 1986. Biotechnology (Reading, Mass.), 24(Table 1), 17-27.

Nalini, E., Jawali, N., Division, A., Atomic, B., Bhagwat, S. G., Agriculture, N., ... Atomic, B. (1999). A simple method for isolation of dna from plants suitable for long term storage and dna marker analysis. (249), 208-214.

Nanvazadeh, F., Dokht, A., \& Reza, M. (2013). Genotyping of Pseudomonas aeruginosa strains isolated from burn patients by RAPD-PCR. Burns, 39(7), 1409-1413. https://doi.org/10.1016/j.burns.2013.03.00 8

Park, G., Way, B., Park, A. B., \& Road, N. (1989). volume 17 Number 71989 Nucleic Acids Research. 17(7), 2503-2516.

Patel, S. H., Bosamia, T. C., Bhalani, H. N., Singh, P., \& Kumar, A. (2015). Polymerase Chain Reaction (PCR). In Agrobios Newsletter: A Monthly Magazine of Agricultural and Biological Sciences (XIII, p. 148). Agrobios newsletter: Magazine of Agricultural and Biological Science.

Pfaffl-Kubista-Vandesompele-real-time-PCRchapter-5.pdf. (n.d.).

Pierce, K. E., \& Wangh, L. J. (n.d.). 7. 65-85.

Poddar, S. K. (2000). Symmetric vs asymmetric PCR and molecular beacon probe in the detection of a target gene of adenovirus. 2532. https://doi.org/10.1006/mcpr.1999.0278

Ponce, M. R., \& Lmicol, J. (1992). PCR amplification of long DNA fragments. 20(3), 91125.

Quan, P., Sauzade, M., \& Brouzes, E. (2018). dPCR: A Technology Review. https://doi.org/10.3390/s18041271

Q Nabi, A., Vernile, A., Spano, G., Lasalandra, G., Beneduce, L., Colelli, G., \& Massa, S. (2011). PCR-based quality control of Listeria spp. and L. monocytogenes in ready-to-eat salads sold in Italy. Current Nutrition \& Food Science, $7(1), 57-62$. doi:10.2174/157340111794941102 
Raeymaekers, L. (2000). Basic principles of quantitative PCR. Molecular Biotechnology (pp. 15 (2) 115-122). pp. 15 (2) 115-122.

Rahman, M. T., Uddin, M. S., Sultana, R., Moue, A., \& Setu, M. (n.d.). Polymerase Chain Reaction ( PCR ): A Short Review.

Rodríguez-Lázaro, D. (2013). Real-Time PCR in Food Science: Current Technology and Applications (Norfolk, UK: Caister Academic Press).

Rodríguez-Lázaro, D., \& Hernández, M. (2013). Real-time PCR in food science: introduction. Curr. Issues Mol. Biol, 15, 25-38.

Sandberg, M., Lundberg, L., \& Ferm, M. (2003). Real Time PCR for the detection and discrimination of cereal contamination in gluten free foods. 344-349. https://doi.org/10.1007/s00217-0030758-4

Schnell, R. J., Ronning, C. M., \& Knight, R. J. (1995). Identification of cultivars and validation of genetic relationships in Mangifera indica L. using RAPD markers.Theoretical and Applied Genetics (pp. 90 (2), 269-274). pp. 90 (2), 269-274.

Shokohi, T., Soteh, M. B. H., Pouri, Z. S., Hedayati, M. T., \& Mayahi, S. (2010). Identification of Candida species using PCRRFLP in cancer patients in Iran. 28(June), 147-152. https://doi.org/10.4103/02550857.62493

Singer, T., \& Burke, E. (n.d.). DNA Flanking Insertions. 236.

Smith, C. J., \& Osborn, A. M. (2009). Advantages and limitations of quantitative PCR (Q-PCR)based approaches in microbial ecology. FEMS microbiology ecology, 67(1), 6-20. https://doi.org/10.1111/j.15746941.2008.00629.x

Stanek, G., \& Hirschl, A. M. (2001). Multicenter Comparison Trial of DNA Extraction Methods and PCR Assays for Detection of. Society, 39(2), 519-524. https://doi.org/10.1128/JCM.39.2.519

Tabarzad, M., Kazemi, B., Vahidi, H., Aboofazeli,R., Shahhosseini, S., \& NafissiVarcheh, N. (2014). Challenges to design and develop of DNA aptamers for protein targets. I. optimization of asymmetric PCR for generation of a single stranded DNA library. Iranian Journal of Pharmaceutical Research, 13(SUPPL), 133-141. https://doi.org/10.22037/ijpr.2014.1468

Tahmasebi, P., Farnia, P., Sheikholslami, F. M., \& Velayati, A. A. (2012). Rapid identification of extensively and extremely drug resistant tuberculosis from multidrug resistant strains; using PCR-RFLP and PCR-SSCP.
Iranian Journal of Microbiology, 4(4), 165170.

Taylor, P., Poms, R. E., Klein, C. L., \& Anklam, E. (2007). Methods for allergen analysis in food: a review Methods for allergen analysis in food: a review. https://doi.org/10.1080/02652030310001 620423

Ugozzoli, L., Yam, P., Petz, L. D., Ferrara, G. B., Champlin, R. E., Forman, S. J., ... Wallace, R. B. (1991). Amplification by the polymerase chain reaction of hypervariable regions of the human genome for evaluation of chimerism after bone marrow transplantation. Blood, 77(7), 1607-1615. https://doi.org/10.1182/blood.v77.7.1607. bloodjournal7771607

Valasek, M. A., \& Repa, J. J. (2005). The power of real-time PCR. Advances in physiology education, 29(3), 151-159. doi:10.1152/advan.00019.2005.

Vos, P., Hogers, R., Bleeker, M., Reijans, M., Lee, T. Van De, Hornes, M., ... Zabeau, M. (1995). AFLP: A new technique for DNA fingerprinting. Nucleic Acids Research, 23(21), 4407-4414. https://doi.org/10.1093/nar/23.21.4407

Wahyuni, S., Xu, D. H., Bermawie, N., Tsunematsu, H., \& Ban, T. (2004).Wahyuni, S., Xu, D. H., Bermawie, N., Tsunematsu, H., \& Ban, T. (2004). (n.d.). Skrining Issr Primer Studi Pendahuluan. 33-42.

Zhiqing Huang, Christopher F. Bassil, and S. K. M. (2017). Ovarian Cancer Including Fallopian Tube Cancer and Primary Peritoneal Cancer. Clinical Practice Guidelines, 1049(version 4), 1-124. https://doi.org/10.1007/978-1-62703-5477

Zietkiewicz, E., Rafalski, A., \& Labuda, D. (1994). Genome fingerprinting by simple sequence repeat (SSR)-anchored polymerase chain reaction amplification. Genomics, Vol. 20, pp. 176-183. https://doi.org/10.1006/geno.1994.1151

Zong, C., Lu, S., Chapman, A. R., \& Xie, X. S. (2012). Genome-wide detection of singlenucleotide and copy-number variations of a single human cell. Science, 338(6114), 1622-1626. https://doi.org/10.1126/science.1229164

Zuo, Z., \& Jabbar, K. J. (2016). COLD-PCR: Applications and advantages. Methods in Molecular Biology, 1392, 17-25. https://doi.org/10.1007/978-1-4939-33600_2 